\title{
SOCIAL RESPONSIBILITY AND BUSINESS ETHICS
}

Natal'ya Oleinik, Igor' Zaharov

Sumy State University, Sumy, Ukraine

Corporate social responsibility is the commitment of businesses to behave ethically and to contribute to sustainable economic development by working with all relevant stakeholders to improve their lives in ways that are good for business, the sustainable development agenda, and society at large.

Pressure from consumers, shareholders and activists has made corporate social responsibility a hot topic. Many businesses are proud that they meet specific employment and environmental standards and are keen to embed social responsibility compliance throughout the supply chain. But there are some who have been predicting - even wishing - for its demise for some time. Followers of such economists as Milton Friedman argue cynically that social responsibility is nothing better than a PR exercise and the only socially responsible thing a company should do is make money for its shareholders. Those advocating increased social responsibility come from a variety of perspectives. Some resent corporate power and influence in general. Others want business to take "greater account of its social and environmental - as well as its financial-footprints".

Over the past decade, corporate social responsibility has risen in global prominence and importance. Corporate governance scandals such as those at WorldCom, Enron, Parlamat, Daewoo, and Tyco profoundly affected major capital markets worldwide, and placed issues such as ethics, accountability, and transparency firmly on the business, regulation and policy agendas. Additionally, issues such as peace, sustainable development, security, poverty alleviation, environmental quality and human rights are becoming increasingly interlinked, and are having a profound effect on businesses and the business environment. Although not traditionally responsible for finding solutions to these challenges, it is in the private sector's best interest to be part of the solution rather than part of the problem.

The main part of the social responsibility is business ethics. The concept has come to mean various things to various people, but generally it's coming to know what it right or wrong in the workplace and doing what's right - this is in regard to effects of products and in relationships with stakeholders. Wallace and Pekel explain that attention to business ethics is critical during times of fundamental change - times much like those faced now by businesses, both nonprofit and for-profit. In times of fundamental change, values that were previously taken for granted are now strongly questioned. Many of these values are no longer followed. Consequently, there is no clear moral compass to guide leaders through complex dilemmas about what is right or wrong. Attention to ethics in the workplace sensitizes leaders and staff to how they should act.

While it would be wrong to confuse social responsibility with ethical business behavior - the two are different beasts with disparate processes and outcomes - they are symbiotic, with one feeding off the other. Business ethics is a tool to meet two important enterprise goals. It is a tool to help managers ensure that their employees and other agents comply with legal minimums. One must never lose sight of that goal. It is also a tool to help managers move beyond merely complying with rules and regulations. This allows them to set another, higher goal: to help lay the foundation for good business practices and functioning market economies for all.

There are two Broad Areas of Business Ethics:

1. Managerial mischief. Madsen and Shafritz, explain that "managerial mischief" includes "illegal, unethical, or questionable practices of individual managers or organizations, as well as the causes of such behaviors and remedies to eradicate them." There has been a great deal written about managerial mischief, leading many to believe that business ethics is merely a matter of preaching the basics of what is right and wrong. More often, though, business ethics is a matter of dealing with dilemmas that have no clear indication of what is right or wrong.

2. Moral mazes. The other broad area of business ethics is "moral mazes of management" and includes the numerous ethical problems that managers must deal with on a daily basis, such as potential conflicts of interest, wrongful use of resources, mismanagement of contracts and agreements. 
Many people are used to hearing of the moral benefits of attention to business ethics. However, there are other types of benefits, as well. The following list describes various types of benefits from managing ethics in the workplace.

3. Attention to business ethics has substantially improved society.

4. Ethics programs help maintain a moral course in turbulent times.

5. Ethics programs cultivate strong teamwork and productivity.

6. Ethics programs support employee growth and meaning.

7. Ethics programs are an insurance policy -- they help ensure that policies are legal.

8. Ethics programs help avoid criminal acts "of omission" and can lower fines.

9. Ethics programs help manage values associated with quality management, strategic planning and diversity management -- this benefit needs far more attention.

10. Ethics programs promote a strong public image.

Unfortunately, few companies, particularly in Ukraine, have the skills or competencies to work in this new operating environment. Strategic capacity-building is imperative in educating these businesses about social responsibility, so they may access new markets and improve their competitiveness on a national, regional and global scale. Increasingly business is operating in complex, tangled environments with multiple stakeholders. And if they are to future-proof their businesses, ensure happy workers, avoid negative publicity and brand damage and generally develop more profitable practices, then is not a choice but a necessity. 